\title{
KAJIAN MODAL SOSIAL PEKERJA DI KEBUN SAWIT KELURAHAN TANI AMAN KECAMATAN LOA JANAN ILIR KOTA SAMARINDA
}

\section{STUDY OF OCIAL CAFITAL FOR WORKERS IN OIL PALM PLANTION TANI AMAN SUBDISTRICT LOA JANAN ILIR DISTRICT SAMARINDA CITY}

\author{
Neneng Anjarwati ${ }^{* 1}$, Rossy Mirasari ${ }^{1}$, Fathiah $^{1}$ \\ ${ }^{1}$ Politeknik Pertanian Negeri Samarinda, Kampus Gunung Panjang, Jl. Samratulangi, \\ Samarinda, Indonesia \\ anjarwatineneng40@gmail.com
}

\begin{abstract}
This researchis motivated by the role of social capital in helping increase the productivity of famers and workers, but not many people admit that increasing human capital increases productivity. This study aims to identify the social capital of workers in oil palm plantions and determine the lovels of social capital of wrkers in oil plam plantions. The data colection techniquis used in this study were directly in the field to distribute questionnaires and interview workers in the oil palm plantions. Then analyzed using the validity of an instrument.

The results of this study are that the level of social capital, namely (trust, network, social norms) owned by workers in te oil palm plantion in Tani Aman Village Loa Janan ilir District Samarinda City is very large. With An average number of trusts of 96. And the decond is networks with an average number of 91.9. and the last is social norms with a ean number of 90.2 with the category of class intervals 88.5-105.2 stongly agree.
\end{abstract}

Keywords: network, social capital, social norms

\section{PENDAHULUAN}

Modal sosial merupakan sesuatu rangkaian proses hubungan antar manusia yang ditopang oleh jaringan, norma-norma dan kepercayaaan sosial yang memungkinkan efisiensi dan efektivitas koordinasi dan kerjasama untuk keuntungan bersama (Hasbullah, 2006). Modal sosial lebih menekankan pada dimensi yang lebih luas yaitu segala sesuatu yang membuat masyarakat atau manusia bersekutu untuk mencapai tujuan bersama atas dasar kebersamaan, dan di dalamnya diikat nilai-nilai dan norma-norma yang tumbuh dan dipatuhi. Hasbullah (2006) mendefinisikan modal sosial sebagai sesuatu yang merujuk ke dimensi institusional, hubunganhubungan yang tercipta, dan normanorma yang membentuk kualitas dan kuantitas hubungan sosial dalam bermasyarakat.

Kesejahteraan sosial berkaitan dengan suatu kondisi sosial dimana masalah-masalah sosial dapat di atasi secara memuaskan, kebutuhan sosial dapat dipenuhi dengan baik, memiliki rasa aman dalam hidup dan kesempatankesempatan sosial terbuka secara bebas (Rukmana, 2009). Kesejahteraan manusia dipengaruhi oleh tiga hal, yaitu: modal alam, modal fisik serta modal manusia dan modal sosial. Jika modal manusia mewakili pengetahuan, keterampilan dan kesehatan, maka modal sosial merujuk pada norma dan jejaring yang memfasilitasi kerjasama antar manusia di dalam kelompok maupun antar kelompok (BPS 2012).

Kondisi modal sosial di daerah pedesaan berbeda dengan modal sosial di daerah perkotaan, khususnya modal sosial pada pekerja dan para petani. Perbedaan tersebut dicirikan dengan masyarakat pedesaan yang sistem kehidupan biasanya berkelompok atas dasar sistem kekeluargaan berbeda dengan mayarakat perkotaan yang pada umumnya dapat mengurus dirinya sendiri 
tanpa harus bergantung kepada orang lain (Soekanto 2013). Masyarakat pedesaan pada umumnya menggantungkan hidupnya pada sektor pertanian salah satunya pertanian kelapa sawit yang biasa nya menjadi tempat pencaharian masyarakat dengan bekerja sebagai pekerja di kebun sawit.

Wahyunindyawati

menyatakan, bahwa belum optimalnya produktivitas dan kurang efisiennya dalam bekerja disebabkan karena tingkat pendidikan petani rendah, modal dan informasi teknologi baru masih kurang,. Usaha peningkatan produktivitas petani atau pekerja dapat dilakukan dengan meningkatkan modal sosial. Pentingnya peranan modal sosial dapat membantu meningkatkan produktivitas para petani dan para pekerja, namun tidak banyak orang mengakui bahwa bertambahnya modal manusia menaikan produktivitas (Mubyarto, 1986). Tingginya nilai modal sosial yang dimiliki suatu daerah dapat membantu para petani dan para pekerja dalam hal produksi, distribusi dan inovasi (Sawitri dan Soepriadi, 2014). Sebagai contoh bila para petani dan para pekerja mengikuti kelompok, kemudian bisa saling meminta bantuan kepada kelompok yang lain, hal tersebut menyatakan bahwa modal sosial dapat mengurangi beban ketika ada kendala.

Beberapa penelitian yang menghasilkan kesimpulan positif terkait dengan pengaruh modal sosial terhadap produktivitas petani adalah seperti penelitian yang dilakukan Kunto Widodo (2015) dengan judul "Analisis Pengaruh Modal Sosial Terhadap Produktivitas Lahan Jagung" (Studi Kasus: Kecamatan Pulokulon, Kabupaten Grobogan), dengan hasil penelitian menunjukkan bahwa variabel modal sosial dapat mengakselerasi produktivitas lahan jagung secarapostitif walaupun penelitian menunjukkan bahwa variabel modal sosial dapat mengakselerasi produktivitas lahan jagung secara postitif walaupun tidak signifikan.

Penelitian ini hanya membahas tentang apa saja modal sosial yang terkait dengan pekerja di kebun sawit dan mengetahui modal sosial terbesar yang dimiliki pekerja di kebun sawit. Tujuan yang ingin dicapai dari penelitian ini adalah untuk mengidentifikasi modal sosial pekerja di kebun sawit dan mengetahui tinggi rendah nya modal sosial pekerja di kebun sawit.

Hasil yang diharapkan dalam penelitian ini sebagai pengetahuan seberapa besar modal sosial yang dimiliki pekerja di kebun sawit.

\section{METODOLOGI}

\section{Metode Pengambilan Data}

a. Wawancara

Pengumpulan data dengan melakukan wawancara langsung dengan para pekerja di kebun sawit. Sebelum melakukan wawancara terhadap para pekerja di kebun sawit peneliti mempersiapkan daftar pertanyaan terlebih dahulu.

b. Kuesioner

Kuesioner yaitu membuat daftar pertanyaan yang digunakan untuk mempermudah dalam mengumpulkan data yang diperlukan dan diajukan kepada responden. Pertanyaan yang ditujukan kepada para pekerja di kebun sawit adalah mengenai identitas responden, modal sosial pekerja yang meliputi kepercayaan, jaringan dan norma sosial.

\section{Analisi Data}

a. Uji Validitas

Uji validitas ini hanya untuk menguji pada setiap instrumen pernyataan dalam kuesioner yang ingin mendapatkan tingkat kevalidan suatu intstrumen Arikunto (2010: 213).

Untuk menentukan kevalidan suatu instrumen dihitung menggunakan rumus uji validitas.

1) Korelasi Product moment dengan simpangan

Rumus Pearson dengan simpangan sebagai berikut:

$$
n y=\frac{\sum x y}{\sqrt{\left(\sum_{x} 2\right)\left(\sum_{y} 2\right)}}
$$


2) Korelasi Product moment dengan angka kasar

Rumus Parson dengan angka kasar sebagai berikut:

$n y=\frac{\mathrm{N} \sum \mathrm{XY}-\left(\sum \mathrm{X}\right)\left(\sum \mathrm{Y}-\right)}{\sqrt{\left(\left(\mathrm{N} \sum \mathrm{X}^{2}-\left(\sum \mathrm{X}^{2}\right)\right)\left(\mathrm{N} \sum \mathrm{Y}^{\left.2-\left(\sum Y\right)^{2}\right)}\right.\right.}}$

Keterangan :

rxy : koefisein korelasi antara variabel $\mathrm{X}$ dan $\mathrm{Y}$

$\sum x y$ : jumlah perkalian antara variabel $X$ dan $Y$

$\sum x^{2}$ : jumlah dari kuadrat nilai $\mathrm{X}$

$\sum y^{2} \quad$ : jumlah dari kuadrat nilai

$\left(\sum x\right)^{2}$ : jumlah nilai $X$ kemudian di kuadratkan

$(\Sigma y)^{2}$ : jumlah nilai $\mathrm{Y}$ kemudisn di kuadratkan

b. Uji Reliabilitas

Reliabilitas hanya menunjuk pada suatu instrument pernyataan kuesioner bahwa suatu instrument pernyataan kuesioner cukup dapat dipercaya untuk digunakan sebagai alat pengumpul data karena instrumen tersebut sudah baik Arikunto (2010). Dengan menggunakan rumus:

$r 11=\left(\frac{k}{k-1}\right)\left(1-\frac{\sum_{a} b^{2}}{\sigma t^{2}}\right)$

Keterangan :

r11 : realibilitas instrumen

$\sum_{a} b^{2}$ : jumlah varians butir

$\sigma t^{2} \quad$ : varians total

$\mathrm{k}$ : banyaknya butir pertanyaan

\section{HASIL DAN PEMBAHASAN}

\section{Hasil}

a. Hasil uji validitas modal sosial Semua indikator-indikator yang digunakan untuk mengukur variable kepercayaan yang digunakan dalam penelitian ini mempunyai nilai korelasi lebih besar dari 0,433 atau sama dengan $r$ hitung $>r$ table. Semua pernyataan tentang kepercayaan (trust), jaringan (networks), norma sosial (norms) dalam kuesioner dinyatakan valid dan layak untuk pengambilan data.

Tabel 1. Hasil pernyataan tentang kepercayaan (trust), jaringan ( networks), norma sosial (norms)

\begin{tabular}{cccc}
\hline & r-hitung & r-tabel & ket \\
\hline 1 & 0,5443 & 0,433 & $\mathrm{~V}$ \\
2 & 0,7095 & 0,433 & $\mathrm{~V}$ \\
3 & 0,6647 & 0,433 & $\mathrm{~V}$ \\
4 & 0,6286 & 0,433 & $\mathrm{~V}$ \\
5 & 0,4833 & 0,433 & $\mathrm{~V}$ \\
6 & 0,4756 & 0,433 & $\mathrm{~V}$ \\
7 & 0,5452 & 0,433 & $\mathrm{~V}$ \\
8 & 0,4843 & 0,433 & $\mathrm{~V}$ \\
9 & 0,5337 & 0,433 & $\mathrm{~V}$ \\
10 & 0,4991 & 0,433 & $\mathrm{ket}$ \\
\hline & $\mathrm{r}-\mathrm{hitung}$ & $\mathrm{r}$-tabel & $\mathrm{V}$ \\
\hline 1 & 0,4996 & 0,433 & $\mathrm{~V}$ \\
2 & 0,4965 & 0,433 & $\mathrm{~V}$ \\
3 & 0,5289 & 0,433 & $\mathrm{~V}$ \\
4 & 0,6199 & 0,433 & $\mathrm{~V}$ \\
5 & 0,5723 & 0,433 & $\mathrm{~V}$ \\
6 & 0,5252 & 0,433 & $\mathrm{~V}$ \\
7 & 0,5452 & 0,433 & $\mathrm{~V}$ \\
8 & 0,4843 & 0,433 & $\mathrm{~V}$ \\
9 & 0,6138 & 0,433 & $\mathrm{~V}$ \\
10 & 0,5373 & 0,433 &
\end{tabular}




\begin{tabular}{cccc}
\hline & r-hitung & r-tabel & ket \\
\hline 1 & 0,5942 & 0,433 & $\mathrm{~V}$ \\
2 & 0,6127 & 0,433 & $\mathrm{~V}$ \\
3 & 0,5723 & 0,433 & $\mathrm{~V}$ \\
4 & 0,5252 & 0,433 & $\mathrm{~V}$ \\
5 & 0,5723 & 0,433 & $\mathrm{~V}$ \\
6 & 0,5252 & 0,433 & $\mathrm{~V}$ \\
7 & 0,4879 & 0,433 & $\mathrm{~V}$ \\
8 & 0,6138 & 0,433 & $\mathrm{~V}$ \\
9 & 0,542 & 0,433 & $\mathrm{~V}$ \\
10 & 0,5804 & 0,433 & \\
\hline
\end{tabular}

b. Uji Reliabilitas

Untuk mengukur reliable tidaknya alat ukur memiliki nilai Cronbach's Alpha > 0,60.seluruh pernyataan yang berkaitan dengan variabel modal sosial dalam kuesioner dinyatan reliabel. Dapat dilihat pada tabel 2.

Tabel 2. Hasil Uji Reliabilitas

\begin{tabular}{|l|l|l|}
\hline \multicolumn{1}{|c|}{ Modal sosial } & Koefisien cronbach alpha & \multicolumn{1}{|c|}{ Keterangan } \\
\hline Kepercayaan (truts) & 0,855 & Sangat tinggi \\
\hline Jaringan (Networks) & 0,793 & Tinggi \\
\hline Norma sosial (Norms) & 0,824 & Sangat tinggi \\
\hline
\end{tabular}

\section{Pembahasan}

a. Hasil Uji Validitas Modal Sosial Semua indikator-indikator yang digunakan untuk mengukur variable Kepercayaan (Trust), Jaringan (Networks), Norma sosial (Norms) yang digunakan dalam penelitian ini mempunyai nilai korelasi lebih besar dari 0,433 atau sama dengan $r$ hitung $>r$ table sehingga dapat disimpulkan bahwa semua indikator kepercayaan tersebut valid. Hasil Uji Reliabilitas dinyatan reliabel Dengan kata lain bahwa seluruh pernyataan yang berkaitan dengan variable modal soial pada penelitian ini memiliki tingkat yang baik dan dapat digunakan dalam analisis data pada penelitian ini.Berdasarkan deskripsi data penelitian dapat diketahui bahwa Kepercayaan (Trust), Jaringan (Networks), Norma sosial (Norms) pada pekerja di kebun sawit kelurahan tani aman, kecamatan loa janan samarinda ilir, termasuk dalam kategori tinggi karena memiliki kelas interval 88.5-105.2 yang artinya mayoritas responden menjawab sangat setuju mereka dapat bekerja sama dalam meningkatkan kualitas kerja dan mereka juga berkomunikasi dengan baik dalam hal apapun atau kendala apapun, dengan adanya menjalin komunikasi pekerja bisa menyelesaikan permasalahan atau kendala dalam bekerja, dengan alasan pekerja ingin menjalin hubungan baik dengan sesama pekerja, mereka bisa saling bertukar pengalaman agar bisa diterapkan dalam bekerja dan bisa menghasilkan kualitas bekerja lebih baik lagi, mereka ingin selalu berusaha dalam bekerja dengan cara selalu berinteraksi dengan baik mencari waktu luang untuk saling bercerita atau bertanya jika ada kendala dalam bekerja.

\section{KESIMPULAN}

1. Terdapat analisis modal sosial berdasarkan kepercayaan (Trust) dengan rata-rata 96 dan masuk 
dalam katagori kelas interval 88.5105.2 sangat setuju..

2. Terdapat analisis modal sosial berdasarkan jaringan (Networks) dengan rata-rata 91.9 dan masuk dalam katagori kelas interval 88.5105.2 sangat setuju.

3. Terdapat analisis modal sosial berdasarkan norma sosial (Norms) dengan rata-rata 90.2 dan masuk dalam katagori kelas interval 88.5105.2 sangat setuju. .

\section{DAFTAR PUSTAKA}

Arikunto (2010: 213).Uji Reabilitas

Fukuyama, F. 1995. Trust : The Social Virtues and The Creation of Prosperity. New York: Free Press. 2002. Trust: Kebajikan Sosial dan Penciptaan Kemakmuran. Yogyakarta: Qalam.

Hasbullah. 2016. Modal social . Jakarta : MR-United Press.

Humairoh, Risqi. 2011. Peranan Modal Sosial Dalam Pengembangan Nilai Kewirausahaan (Kasus Pedagang Kecil dan Anggota Kelompok Tani di desa cikarang Kecamatan Dramaga kabupaten bogor). Sinopsis
Menurut Sugiyono 2017:85. Tehnik sampling jenuh.

Putnam, R. 2000. Bowling alone: The collapse and revival of American Community. NewYork: Simonand Schuster.

Putnam, R. D. 1993. Making Democracy Work: Civic Traditions in Modern Italy. Princeton: Princeton University. Reijntjes, C.dkk. 1999. Pertanian Masa Depan; Pengantar Untuk Pertanian Berkelanjutan Dengan Input Luar Rendah.Yogyakarta : Kanisius

Rusmana. 2009. Pembangunan Sosial : Model dan Indikator. Bandung : STKSPRESS.

Rukmana, 2009:23). Modal sosial.,

Riduwan. 2010. Skala Pengukuran Variabel-Variabel Penelitian. Alfabeta. Bandung.

Wahyunindyawati, F. Kasijadi dan Heriyanto. 2003. Tingkat Adopsi Teknologi Usahatani Padi Lahan Sawah di Jawa Timur: Suatu Kajian Model Pengembangan "C ooperative Farming". Jurnal Pengkajian dan Pengembangan Teknologi Pertanian 